\title{
Review of Becoming a Library Leader
}

\author{
Rachel Evans \\ University of Georgia
}

\begin{abstract}
Review of Freedman, James M. and Freedman, Shin (Ed.) (2020). Becoming a library
leader: Seven stages of leadership development for academic librarians. Chicago: Association of College and Research Libraries.
\end{abstract}

Keywords: academic libraries, academic librarian, leadership, academia, promotion, mentorship

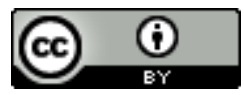

This is an Open Access article distributed under the terms of the Creative Commons Attribution 4.0 International License (http://creativecommons.org/licenses/by/4.0), which permits unrestricted use, distribution, and reproduction in any medium, provided the original work is properly cited. 
"A journey of a thousand miles begins with a single step." From the introduction's

inclusion of this ancient Chinese saying and the first chapter's Ray Bradbury quote, I resonated with this text. This was a truly unique read for a book of this type. It is a sort of self-help textbook for young librarians, yet like the best fiction I found it hard to put down. Not only aimed at developing leadership skills in aspiring information professionals, it also seeks and succeeds at inspiring and empowering the reader. Like a roadmap complete with workbookstyle activities, I found it easy and even fun to follow along, journaling as I read and completed the tables and questionnaires.

Every single section includes such activities. The first was targeted at demystifying leadership. This section tackles the myths of leadership in general (not just in libraries), and asks the reader questions about how they define leaders. Questions included what form leadership takes, and if leaders are always found at the top of a given organization or not. It was an excellent way to start off the journey, self-identifying how we each perceive leadership qualities, roles, and more. One of the biggest takeaways for me from this earliest section was the people-centered awareness chapter one highlighted. There were many qualities outlined in this first chapter that we all expect to see and I think agree on when we think of leader-level qualities: competent, communicating, vision, assertiveness, self-awareness. Yet, the emphasis on having the trust of staff as well as empowering staff was a pleasant surprise, as well as the overarching emotional intelligence that may not be traditionally found in leaders but is certainly far more valuable today than it used to be.

I found myself quickly re-assessing my own idea of what a leader was. For example, I used to accept the myth that a leader was found at the top of an organization. After completing activity prompts and journaling about my own experiencing from being a part-time library Journal of New Librarianship, 5(2020) pp. 195-199 10.21173/newlibs/9/19 195 
assistant to a graduate student to a library staff member, and most recently a professional librarian, I realized that indeed leadership comes from those who take on opportunity and responsibility, and beyond that from those that empower them to do so. It is not uncommon to find poor leadership at the top of an organization. Great leadership is found in those individuals that have driven themselves to that point.

Another activity that I enjoyed early in the book was that of identifying leaders in my own library. This exercise encouraged me to identify examples of various types of leaders. The absent leader is one I have dealt with on a recurring basis throughout my life. According to this text, the absent leader delegates everything, but rarely contributes anything themselves. They often take advantage of their employee's skills and other strengths. In some cases this can serve to empower others by giving them autonomy as well as experience. In other cases it can grow resentment, especially over a long period of time if employees feel their supervisor is taking credit for their work product as their own.

This section of the book had me heavily journaling about and thinking deeply on the perceived and real divisions in management and rank in the organizations I have worked for. Many setbacks and even major barriers between leaders and their employees can come from small but repeated burn outs where poor communication is concerned. Building trust is a long and often slow process that can very quickly break under pressure. This was a motivational moment for me. Having finished reading these sections and completing the activities I better understood how important it is to empower people, whether that is thanking them for their contributions (however small) or giving them the tools they need to accomplish things in the workplace. 
Another section of the book that particularly resonated with me was when the text defined the differences between "management" and "leadership". The two terms as so very frequently used interchangeably, but they do indeed have unique definitions. In this segment an example was given of the "Top 10 I.T. Issues", and since I came to librarianship through an information technology department and role, this perfectly drove the point home for me. First hand I have countless times over dealt with management versus leadership. In a nutshell, management is primarily concerned with keeping established procedures, measuring known quantities, and being efficient above all. In a single phrase, managers "do things right", or in a single word, they "maintain". Leadership on the other hand is visionary, using persuasion and motivation to be more effective than efficient. In a single phrase, leaders "do the right thing", or in a single word, they "innovate".

Following these very helpful definitions an activity prompts the reader to identify specific managers and leaders in your library. This was surprisingly easy to do! And as I described in my notebook the individuals I felt had been very successful managers and others that I felt were great leaders, I was further amazed to begin visualizing my personal ideal leader. They would no doubt be an individual who embodied both "manager" and "leader" traits in a combination that while difficult to achieve is the kind of person I hope to work for, and eventually become. Of course, the hardest part of this activity was the self-assessment moment. You ask yourself "Where do I fall on the list? Am I a manager or a leader?" Other key questions you are prompted to ask yourself through the test following the exercise are "How do others see you?" and "Does your organization prefer managers or leaders?". There can be major clashes in an organization when a leader is in a manager's role, or a manager winds up in a leadership position. 
This book is like a wonderful rabbit hole. When I expressed that it was a journey, I was not kidding! One question leads to another, and then another. Following your own identification of managers and leadership, and further observing what your current organization values inevitably brings you to unraveling the history. I ended up exploring the how and why of my organization's micro and macro structure, and trying to piece together like a detective the work, time, and professional luck or successes that lead the various individuals in my library to their current positions. Again, no surprise that I feel like I ended up learning more about myself than I did about the people in various positions at my current workplace.

There were other activities that had you make observations about your work environment. What are the various generations in the workplace? How do they interact? What are the generational make-ups of the managers, leaders, and staff? Who among them makes the decisions, or is it a group effort? Who initiates conversations and other gatherings? When socializing takes place, how are the dynamics divided and how organic are the comments and communications? Who in the workplace is the most productive and who is most responsible (are those people at the top or not)? These questions felt small on the surface but answering them proved to be more difficult as it forces you to really dissect your organization, revealing what and who are truly valued, as well as who the true leaders are among the library.

Mentorship was another important factor in this book, and as the chapters progressed it became more apparent how valuable good mentoring can be to achieving your goals in any career. For information professionals, a variety of both formal and informal mentoring relationships can be formed to provide support and advice as you pursue your goals of becoming a leader. Some attention was given to defining mentorship versus coaching. Surprisingly, with so much talk about mentorship in many professions today, the concept still Journal of New Librarianship, 5(2020) pp. 195-199 10.21173/newlibs/9/19 198 
remains quite mysterious. This book did an excellent job of breaking down both the how and why of such key professional relationships, including discussion about networking effectively. Just as earlier in the book activities helped to identify leaders, this section helps you identify mentors (perhaps even some your already have but did not realize, as can be the case with peer-mentoring!). My favorite quote from the mentoring section was, "with an abundance of continuing education info and so many opportunities, a mentor helps sort through and synthesize the vital signal from the noise". It even delves into reverse mentoring and provides tips for being "coachable".

So, how can we aspiring leaders be perceived by those around as having great potential for leadership? This is a little bit like the advice of "dress for the job you want, not the job you have". Coming from all that I learned in the earliest parts of this book, the reader gathers ideas, traits and goals to compose a checklist of what their ideal leader (or their future self) should include:

- $\quad$ Be genuine

- Praise others for their good work (and articulate what they did well)

- Have clear, measurable goals (make sure they relate to your organization's)

- Practice empathy (work on perceiving what others need - listen more often)

- Ask questions (and ask the right questions, while suspending judgement)

- Practice positivity in the workplace (this can contribute to productivity) As with all great books for information professionals, each and every chapter included extensive bibliographies for further reading. I was able to put my readings into practice right away. I look forward to returning to this text again and again. I highly recommend it. 